\title{
Inhibition of Monocyte Chemotactic Protein-1 Synthesis by Statins
}

\author{
Maria Romano, Luisa Diomede, Marina Sironi, Lucia Massimiliano, \\ Marcello Sottocorno, Nadia Polentarutti, Angelo Guglielmotti, Diego Albani, \\ Alessandra Bruno, Paolo Fruscella, Mario Salmona, Annunciata Vecchi, \\ Mario Pinza, and Alberto Mantovani
}

\begin{abstract}
Department of Molecular Biochemistry and Pharmacology (MR, LD, MS, DA, AB, PF, MS) and Department of Immunology (MS, LM, NP, AV, AM), Istituto di Ricerche Farmacologiche "Mario Negri," Milan, and Angelini Ricerche $\operatorname{SpA}(A G, M P)$, Rome, and Department of Biotechnology (AM), University of Brescia, Brescia, Italy
\end{abstract}

\begin{abstract}
SUMMARY: The beneficial effects of statins on the reduction of cardiovascular events has been partly attributed to their anti-inflammatory properties. In the complex of the different pathogenetic events leading to atherosclerosis, recent data suggest a central role of monocyte chemotactic protein-1 (MCP-1), because mice knock-out for MCP-1 or its receptor CC-chemokine receptor 2 were considerably resistant to plaque formation. In this study we investigated the effect of different statins on in vitro and in vivo production of MCP-1. Lovastatin and simvastatin caused a dose-dependent inhibition of MCP-1 production in peripheral blood mononuclear cells exposed to lipopolysaccharide or inactivated Streptococcus hemoliticus and in human endothelial cells exposed to interleukin-1 $\beta$. The addition of mevalonate overrode the inhibitory effect of statins indicating that mevalonate-derived products are important for chemokine production. The in vivo anti-inflammatory effect of statins was investigated using the mouse air-pouch model of local inflammation. Lovastatin and pravastatin were orally administered to mice according to a treatment schedule that significantly inhibited the hepatic 3-hydroxy-3-methylglutaryl coenzyme A reductase activity without affecting total blood cholesterol. At the dose of $10 \mathrm{mg} / \mathrm{kg}$, lovastatin and pravastatin reduced by approximately $50 \%$ the lipopolysaccharide-induced leukocytes recruitment and the exudate MCP-1 production. In conclusion, statins, by inhibiting mevalonate-derived products, reduced both in vitro and in vivo the production of chemokines involved in leukocyte migration, and this effect is unrelated to their cholesterol-lowering action. (Lab Invest 2000, 80:1095-1100).
\end{abstract}

$T$ he enzyme 3-hydroxy-3-methylglutaryl coenzyme A (HMG-CoA) reductase catalyzes the conversion of HMG-CoA to mevalonic acid, representing the rate-limiting step in the biosynthetic production of cholesterol (Goldstein and Brown, 1990). Statins, inhibiting HMG-CoA reductase activity, lower cholesterol by decreasing the production of low-density lipoproteins (LDL) and up-regulating the expression of LDL-receptor (Goldstein and Brown, 1990). These drugs are widely used in primary and secondary prevention of coronary artery diseases because of their efficacy in reducing cardiovascular morbidity and mortality (Anonymous, 1998; Anonymous, 1994; MacMahon et al, 1998). Recent trials demonstrated that statin therapy has a beneficial effect also in patients with normal or low cholesterol levels (Downs et al, 1998; Ridker et al, 1998), suggesting that these drugs may also act on nonlipid determinants involved in the inflammatory-fibroproliferative phenomenon that accompanied the atherosclerotic process (Vaughan et al, 1996).

\section{Received March 30, 2000}

Address reprint requests to: Luisa Diomede, Department of Molecular Biochemistry and Pharmacology, Istituto di Ricerche Farmacologiche "Mario Negri," Via Eritrea 62- 20157 Milano-Italy; Fax: 0039-23546277; E-mail: diomede@irfmn.mnegri.it
Increasing evidence suggests that statins, by inhibiting mevalonate-derived products synthesis, limit also the production of molecules playing important roles in the inflammatory process associated with plaque formation and stabilization (Kluft et al, 1999; Rosenson et al, 1999; Vaughan et al, 1996). Experimental evidence supports this, by showing that the in vitro inhibition of mevalonate synthesis induced apoptosis of rat vascular smooth muscle cells (Guijarro et al, 1998) and decreased the proliferation of rat mesangial cells (O'Donnell et al, 1993). Moreover, the inhibition of isoprenoid synthesis reduced the production of interleukin (IL)-8 and IL-6 in THP-1 cells, a myeloid leukemia cell line with a mature monocyte phenotype, treated with lipopolysaccharide (LPS) or phorbol myristate acetate (Ikeda and Shimada, 1999; Terkeltaub et al, 1994). The production and expression of monocyte chemotactic protein-1 (MCP-1) in response to fetal bovine serum was also inhibited by lovastatin in fetal human mesangial cells (Kim et al, 1995) and in vivo in nephrotic rats (Park et al, 1998).

Monocyte recruitment is an early step in the initiation of atherosclerotic process. Several lines of evidence implicated MCP-1, a CC chemoattractant protein playing an important role in monocyte recruitment (Rollins, 1997; Sozzani et al, 1996), in the pathogenesis of atherosclerosis (Reape and Groot, 1999; Takeya 
et al, 1993). In particular, mice with genetic inactivation of MCP-1 or its CC-chemokine receptor 2 (CCR2) were reported to be considerably resistant to the development of atherosclerosis (Boring et al, 1998; Gu et al, 1998; Reape and Groot, 1999). These observations prompted us to investigate whether statins affect in vitro the MCP-1 production using human endothelial cells and peripheral blood monocytes. The ability of statins to affect leukocyte migration and chemokine production in vivo was also investigated by using the mouse air-pouch model of local inflammation. The data obtained here indicate that mevalonate-derived products are required, both in vitro and in vivo, for chemokine production.

\section{Results and Discussion}

The effect of HMG-CoA reductase inhibitors on chemokine production was investigated here using cells actively involved in the atherogenic process, such as circulating monocytes and endothelial cells (Ross, 1993). To this end, human peripheral blood mononuclear cells (PBMC) and human endothelial cells (EC) were treated for 24 hours with increasing concentrations of lipophilic inhibitors of HMG-CoA reductase, lovastatin or simvastatin (0.1-40 $\mu \mathrm{M})$, before the exposure to inflammatory stimuli. Pravastatin, a hydrophilic statin, was not considered for these studies because of its reported lack of activity in vitro on smooth muscle cell migration, proliferation, and apoptosis (Corsini et al, 1995b, 1998; Guijarro et al, 1998) and for its weaker inhibitory effect on sterol synthesis (Kurakata et al, 1996; van Vliet et al, 1996). As shown in Figure 1A, lovastatin and simvastatin, at 10 and 40 $\mu \mathrm{M}$, significantly reduced $\mathrm{MCP}-1$ production induced in PBMC by $100 \mathrm{ng} / \mathrm{ml}$ LPS ( $p \leq 0.01$, Student's $t$ test) or $0.005 \mathrm{KE} / \mathrm{ml}$ inactivated Streptococcus hemoliticus ( $p \leq 0.01$, Student's $t$ test), whereas doses below 10 $\mu \mathrm{M}$ were ineffective. The effect of statins on EC exposed to $1 \mathrm{ng} / \mathrm{ml} \mathrm{IL-1 \beta}$ was more pronounced: a significant inhibition of MCP-1 production was seen for concentrations $\geq 0.6 \mu \mathrm{M}$ for lovastatin and $\geq 0.3$ $\mu \mathrm{M}$ for simvastatin (Fig. 1B). In fact, the ED50 values calculated for PBMC and EC were 14.2 and $0.79 \mu \mathrm{M}$, respectively, for lovastatin, and 7.2 and $0.56 \mu \mathrm{M}$, respectively, for simvastatin, showing a higher activity of simvastatin compared with lovastatin on chemokine production by human cells in vitro. Simvastatin was reported to be more active than lovastatin in inhibiting microsomal HMG-CoA reductase from rat, hamster, or dog liver, and from the human hepatoma cell line HepG2 (Corsini et al, 1995a).

The results obtained in this study indicated that the effective dose of statins depends on the type of target cells (Kluft et al, 1999; van Vliet et al, 1996), and was in accordance with previous data showing that cytokine production (IL-6 and IL-8) in the myeloid leukemia THP-1 cell line was inhibited at lovastatin and fluvastatin concentrations of $10 \mu \mathrm{M}$ (lkeda and Shimada, 1999; Terkeltaub et al, 1994), whereas MCP-1 production by human fetal mesangial cells, vascular smooth muscle cells, or U937 cells (Kim et al, 1995; Ortego et al, 1999) was inhibited at a concentration of $1 \mu \mathrm{M}$.

There are no data on the effectiveness of statins in inhibiting HMG CoA-reductase activity in human EC: Table 1 shows a dose-dependent reduction in cellular enzyme activity after treatment with lovastatin. Interestingly, the lowest concentration able to significantly inhibit the HMG-CoA reductase activity $(0.6 \mu \mathrm{M}$, Table 1) corresponded to the minimal dose of lovastatin required to significantly ( $p \leq 0.01$ ) inhibit $\mathrm{MCP}-1$ production (Fig. 1B), strongly suggesting that the inhibition of this enzymatic pathway is relevant for MCP-1 synthesis.

To determine whether the ability of statins to reduce chemokine production depends on their capacity to inhibit mevalonate synthesis, cells were treated with lovastatin or simvastatin in the presence of mevalonate (from 25 to $100 \mu \mathrm{M}$ ). As shown in Figure 2, the addition of mevalonate at 50 and $100 \mu \mathrm{m}$ overrode the inhibitory effect of both statins in EC exposed to IL-1 $\beta$,
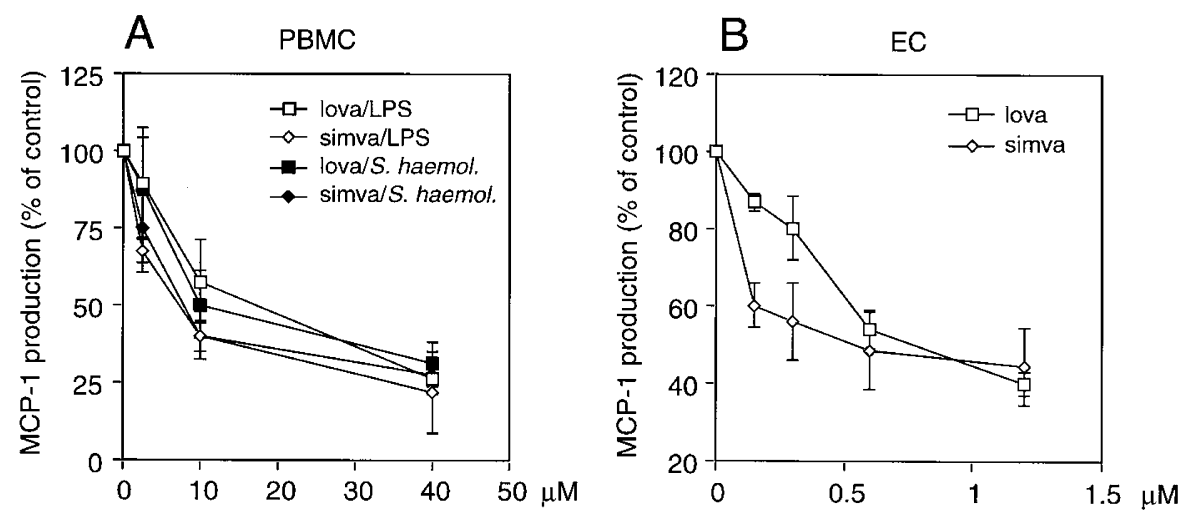

\section{Figure 1.}

In vitro inhibition of monocyte chemotactic protein-1 production by statins. Cells were exposed to lovastatin or simvastatin (0.1-40 $\mu \mathrm{M})$ for 24 hours. Controls received medium alone. After washing, cells were cultured for an additional 24 hours with or without statin, in the presence or the absence of stimuli. Lipopolysaccharide (LPS) at $100 \mathrm{ng} / \mathrm{ml}$ or Streptococcus hemoliticus at $0.005 \mathrm{KE} / \mathrm{ml}$ were used as stimuli for peripheral blood mononuclear cells (PBMC) (A), whereas $1 \mathrm{ng} / \mathrm{ml}$ of IL-1 $\beta$ was used for endothelial cells (EC) (B). Monocyte chemotactic protein-1 (MCP-1) production in cellular supernatants was measured by ELISA, as described in the Materials and Methods section, and expressed as a percentage of control. Values are the mean \pm standard error of at least four experiments. 
Table 1. Effect of Lovastatin on HMG-CoA Reductase Activity in EC Cells ${ }^{a}$

\begin{tabular}{cc}
\hline $\begin{array}{c}\text { Lovastatin } \\
(\mu \mathrm{M})\end{array}$ & $\begin{array}{c}\text { HMG-CoA reductase } \\
(\mathrm{pmol} / \mathrm{min} / \mathrm{mg} \text { protein })\end{array}$ \\
\hline 0 & $40.50 \pm 2.81$ \\
0.3 & $37.18 \pm 4.00$ \\
0.6 & $30.91 \pm 2.62^{\star \star}$ \\
1.2 & $27.03 \pm 4.01^{\text {** }}$ \\
\hline
\end{tabular}

${ }^{a}$ Endothelial cells (EC) were exposed for 3.5 hours to $0.3-1.2 \mu \mathrm{M}$ of lovastatin. At the end of incubation, the medium was removed, cells were scraped, and the activity of HMG-CoA reductase was determined as described in the Materials and Methods section. Values are the mean \pm standard deviation of at least 6 different samples.

${ }^{* *} p \leq 0.01$ vs untreated cells.

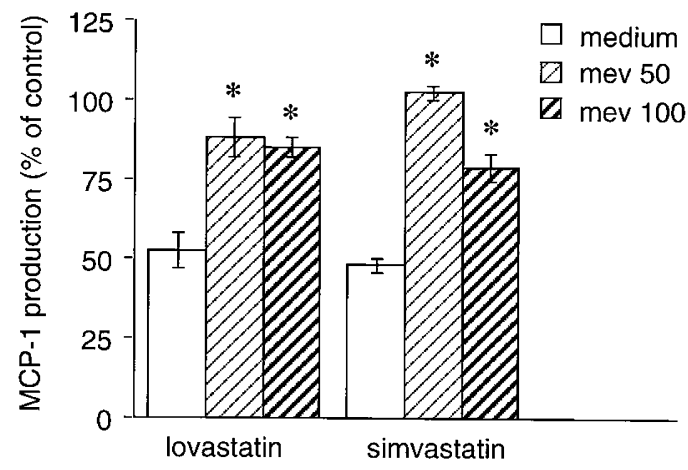

Figure 2.

Recovery of statin-induced inhibition of monocyte chemotactic protein-1 production by mevalonate. Endothelial cells (EC) were exposed for 24 hours to $0.6 \mu \mathrm{M}$ of lovastatin and $0.3 \mu \mathrm{M}$ of simvastatin. After washing, cells were cultured for an additional 24 hours, with or without statins, in the presence of $\mathrm{IL}-1 \beta(1 \mathrm{ng} / \mathrm{ml})$ alone or IL-1 $\beta$ plus mevalonate $(50-100 \mu \mathrm{M})$. MCP-1 production in cellular supernatants was measured by ELISA, as described in the "Materials and Methods" section, and expressed as a percentage of control. Values are the mean \pm standard error of at least three experiments. $p \leq 0.01$ versus lovastatin or simvastatin alone.

whereas the $25 \mu \mathrm{M}$ concentration was inactive (data not shown). Mevalonate also restored MCP-1 production induced in PBMC by exposure to LPS or Streptococcus hemoliticus (data not shown), indicating that mevalonate-derived products are relevant for chemokine production.

To determine whether the inhibition of MCP-1 by HMG-CoA reductase inhibitors was mediated through a reduction of mRNA accumulation, a Northern blot analysis of PBMC stimulated with Streptococcus hemoliticus was done. Depending upon the dosage, lovastatin was observed to suppress the mRNA levels for MCP-1 (Fig. 3), indicating that HMG-CoA reductase inhibitors can affect chemokine expression.

Based on these observations, we investigated whether the inhibition of mevalonate synthesis affects leukocyte functions in vivo. For this study we used lovastatin, as a prototype of a lipophilic inhibitor of HMG-CoA reductase activity, and pravastatin, which, because of their different chemical structures, exhibit in vivo diverse pharmacological properties (Bhatnagar, 1998; Pan et al, 1990; Rosenson et al, 1999). The effect of these statins on leukocyte migration and

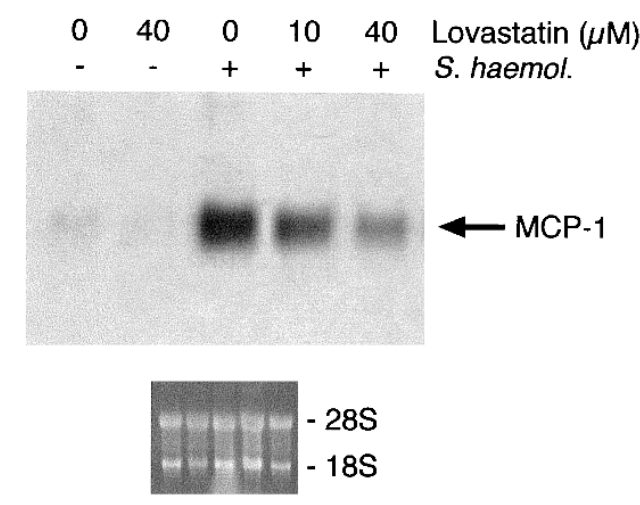

Figure 3.

Effect of lovastatin on monocyte chemotactic protein-1 mRNA expression. PBMC $\left(30 \times 10^{6}\right.$ cells) were cultured for 24 hours with 10 or $40 \mu \mathrm{m}$ of lovastatin. Controls received medium alone. After washing, cells were cultured for an additional 4 hours with or without lovastatin, in the presence or absence of Streptococcus hemoliticus at $0.005 \mathrm{KE} / \mathrm{ml}$. Total RNA was collected, electrophoresed, blotted and hybridised to MCP-1 specific probe, as described in the "Materials and Methods" section. An autoradiograph is shown. Below the Northern blot is an ethidium bromide-stained $1 \%$ agarose gel that contained the total RNA, before blotting analysis for mRNA.

chemokine production was investigated by applying the mouse air-pouch model of local inflammation (Romano et al, 1997). To differentiate the hypolipidemic effect of statins from their anti-inflammatory potential, we focus our attention on the identification of a short-term treatment schedule that significantly lowered hepatic HMG-CoA reductase activity without affecting total blood cholesterol. Based on the results of preliminary experiments in which different doses of statins $(1-20 \mathrm{mg} / \mathrm{kg})$ were applied to mice according to the dose-range generally applied to rodents (Kita et al, 1980; Ness et al, 1994; Park et al, 1998), we defined the dose of $10 \mathrm{mg} / \mathrm{kg} \times 3$ as the optimal one. At this dose, both lovastatin and pravastatin significantly reduced approximately $50 \%$ of the hepatic activity of HMG-CoA reductase without affecting the circulating cholesterol levels (Table 2). Under these conditions, lovastatin and pravastatin similarly reduced the number of total leukocytes recruited in the pouch by 0.2 $\mu \mathrm{g} / \mathrm{mouse}$ of LPS and inhibited the levels of MCP-1 in the exudate (Table 2). The composition of the cellular infiltrate (polymorphs $88.2 \% \pm 2.6$ and monocytes $10.2 \% \pm 5.6$ ) was not modified by the lovastatin treatment (polymorphs $87.9 \% \pm 5.3$ and monocytes $11.7 \% \pm 2.6)$.

The data reported here indicate that the inhibition of HMG-CoA reductase activity, affecting the mevalonate pathway, altered both in vitro and in vivo the generation of MCP-1. This CC chemokine is produced by a variety of cell types, including monocytes, smooth muscle cells, and endothelial cells, all involved in the synthesis of the plaque and the promotion of its instability (Mantovani et al, 1997; Rollins, 1997; Takeya et al, 1993). Recently it was reported that MCP-1 and its receptor CCR2 are actively involved in the progression of atherogenesis (Boring et al, 1998; $\mathrm{Gu}$ et al, 1998). Therefore, the ability of statins to inhibit MCP-1 production may represent an additional, 
Table 2. Effect of Statins on Lipid Profile, Pouch Leukocyte Recruitment, and Exudate MCP-1 Production ${ }^{a}$

\begin{tabular}{lcccc}
\hline \multicolumn{1}{c}{ Treatment } & $\begin{array}{c}\text { Serum cholesterol } \\
(\mathrm{mg} / \mathrm{dl})\end{array}$ & $\begin{array}{c}\text { Hepatic HMG-CoA } \\
\text { reductase } \\
(\mathrm{pmol} / \mathrm{min} / \mathrm{mg} \text { prot. })\end{array}$ & $\begin{array}{c}\text { Leukocytes } \\
\left(\times 10^{6} \text { cells }\right)\end{array}$ & $\begin{array}{c}\text { MCP-1 } \\
(\mathrm{ng} / \mathrm{ml})\end{array}$ \\
\hline CMC & $144.8 \pm 10$ & $6.3 \pm 0.3$ & $0.50 \pm 0.10$ & $2.1 \pm 0.35$ \\
LPS & $134.4 \pm 12$ & $7.0 \pm 0.7$ & $8.24 \pm 1.09$ & $7.5 \pm 0.45$ \\
Lovastatin + LPS & $132.1 \pm 15$ & $3.5 \pm 0.4^{* *}$ & $4.25 \pm 0.91^{*}$ & $5.7 \pm 0.90^{\star *}$ \\
Pravastatin + LPS & $164.8 \pm 37$ & $4.4 \pm 0.3^{* *}$ & $4.20 \pm 0.60^{*}$ & $4.5 \pm 0.95^{\star *}$ \\
\hline
\end{tabular}

\footnotetext{
a Subcutaneous dorsal pouches were created in male CD1 mice as described in the Materials and Methods section. Inflammation was induced on Day 6 by injecting $0.2 \mu \mathrm{g}$ /mouse of lypopolysaccaride (LPS) in $1 \mathrm{ml}$ of $0.5 \%$ carboxymethylcellulose (CMC). Controls received CMC alone. Lovastatin or pravastatin, at the dose of 10 $\mathrm{mg} / \mathrm{kg}$, was orally administered to mice $20 \mathrm{hr}, 12 \mathrm{hr}$, and $15 \mathrm{~min}$ before LPS. Four hours after LPS, mice were killed, the blood collected, and liver was excised. Total serum cholesterol and the hepatic activity of HMG-CoA reductase were determined. Total leukocytes recruited in pouches were counted, and MCP-1 level was determined in the pouch exudate. Values are the mean \pm standard deviation of at least 8 different animals.

${ }^{*} p \leq 0.05,{ }^{* *} p \leq 0.01$ for statin + LPS vs LPS.
}

lipid-unrelated mechanism important for their effect on the reduction of atherosclerotic lesions and cardiovascular-related mortality. Moreover, the present data confirming the anti-inflammatory properties of statins reinforce the hypothesis that MCP-1 inhibitors, acting by inhibiting either agonist production or receptor expression, may also represent innovative pharmacological tools for the prevention of cardiovascular-related diseases in normolipidemic patients.

\section{Materials and Methods}

\section{Reagents}

Reagents used were as follows: RPMI 1640 and M 199 medium (Biochrom KG, Berlin, Germany); penicillin and streptomycin for clinical use (Pharmacia, Nerviano, Italy); Ficoll-Hypaque (Biochrom KG, Berlin, Germany); fetal calf serum (FCS) (Hyclone Laboratories, Logan, Utah), IL-1 $\beta$ (Dompè, L'Aquila, Italy) with a specific activity of $10^{7} \mathrm{U} / \mathrm{mg}$. All the reagents contained less than $0.125 \mathrm{EU} / \mathrm{mL}$ of endotoxin (Limulus Amebocyte Lysate assay; Microbiological Associates, Walkersville, Maryland). Lipopolysaccharide (LPS, from Escherichia coli 055:B5) was from Difco (Detroit, Michigan) and a lyophilised preparation of attenuated strain Su of Streptococcus hemoliticus (Group A, Type 3) was from Chugai Pharmaceuticals Company, Ltd. (Tokyo, Japan). Lovastatin and simvastatin were a gift of Merck Research Laboratories (Rahway, New Jersey) and was converted to the active compound as described (Kita et al, 1980). Pravastatin was obtained from Menarini Laboratories (Florence, Italy) and dissolved in $\mathrm{NaCl} 0.9 \%$.

Mevalonate and mevalonolactone-5-[ $\left[{ }^{3} \mathrm{H}\right]$ (ethanol solution; specific activity $10-40 \mathrm{Ci} / \mathrm{mmol}$ ) were from Sigma Chemicals Company (St. Louis, Missouri). 3-Hydroxy-3-methyl[3- $\left.{ }^{14} \mathrm{C}\right]$ glutaryl-coenzyme A (buffered aqueous solution; specific activity $50-62 \mathrm{mCi} /$ $\mathrm{mmol}$ ) and RS-[2- $\left.{ }^{14} \mathrm{C}\right] \mathrm{mevalonolactone} \mathrm{(toluene} \mathrm{solu-}$ tion; specific activity $50-62 \mathrm{mCi} / \mathrm{mmol}$ ) were from Amersham (Milan, Italy). Rhodamine $G$ was from Merck (Darmstadt, Germany). All other reagents were from Sigma.

\section{Endothelial Cells}

Human EC were obtained from umbilical veins and cultured as described (Romano et al, 1997). We used routinely confluent cells at 2 nd to 6 th passage. Cells at the concentration of $1.5 \times 10^{4} / 0.2 \mathrm{ml}$ were cultured for 24 hours in flat-bottomed 96 well plates (Falcon, Cockeysville, Maryland) in M 199 medium with $20 \%$ FCS, supplemented with $50 \mu \mathrm{g} / \mathrm{ml}$ of Endothelial Cell Growth Supplement (Collaborative Research Inc., Lexington, Massachusetts) and $100 \mu \mathrm{g} / \mathrm{ml}$ of heparin. The medium was replaced with fresh M 199 with 20\% FCS, and statins, alone $(0.1-2.5 \mu \mathrm{M})$ or with mevalonate $(25-100 \mu \mathrm{M})$, were added overnight. EC were then exposed to $1 \mathrm{ng} / \mathrm{ml}$ of IL-1 $\beta$. After 24 hours, supernatants were harvested and kept at $-20^{\circ} \mathrm{C}$ until use. For the evaluation of HMG-CoA reductase activity, EC (confluent monolayer in the 6 well plates) were exposed to different concentrations of lovastatin for 3.5 hours. Then cells were washed and scraped. HMG-CoA reductase activity was evaluated as described below.

\section{Peripheral Blood Mononuclear Cells}

Buffy coats from healthy blood donors (courtesy of Centro Trasfusionale, Ospedale Sacco, Milan, Italy) were used as a source of PBMC, which were isolated by Ficoll-Hypaque gradient. Cells, at $2 \times 10^{5}$ cells/0.2 $\mathrm{ml}$, were cultured in RPMI 1640 with $5 \%$ FCS. Cells were incubated with statins alone $(0.1-50 \mu \mathrm{M})$ or statins $(10 \mu \mathrm{M})$ plus $100 \mu \mathrm{M}$ mevalonate for 24 hours, placed in round-bottomed 96 well plates (Costar Corporation, Cambridge, Massachusetts), and exposed to $100 \mathrm{ng} / \mathrm{ml}$ of LPS or $0.005 \mathrm{KE} / \mathrm{ml}$ of Streptococcus hemoliticus. After 24 hours, supernatants were harvested and kept at $-20^{\circ} \mathrm{C}$ until use.

\section{Northern Blot Analysis}

Northern blot analysis was conducted on PBMC treated for 24 hours with 10 or $40 \mu \mathrm{M}$ lovastatin and then exposed to $0.005 \mathrm{KE} / \mathrm{ml}$ of Streptococcus hemoliticus for an additional 4 hours. RNA preparations were performed according to standard procedures. The MCP-1 probe was prepared and used as already 
described (Sironi et al, 1996). RNA transfer to membranes was checked by UV irradiation, as shown in Figure 3.

\section{Animals}

Male $C_{1}$ mice, 18 to $20 \mathrm{~g}$ body weight (Charles River, Como, Italy), were used. The animals were housed at a constant temperature $\left(20 \pm 1^{\circ} \mathrm{C}\right)$ and relative humidity $(60 \pm 10 \%)$ and supplied ad libitum with water and a standard diet. Procedures involving animals and their care were conducted in conformity with national and international laws and policies (EEC Council Directive 86609, OJ L358, 1, 12 December 1987; Italian Legislative Decree 116/92, Gazzetta Ufficiale della Repubblica Italiana n0.10, 18 February 1992; Guide for the Care and Use of Laboratory Animals, U.S. National Research Council, 1996).

\section{Air-Pouch Model}

Subcutaneous dorsal pouches were created by injection of $5 \mathrm{ml}$ of air followed, 3 days later, by a reinjection of $3 \mathrm{ml}$ of air. On Day $6,0.2 \mu \mathrm{g} /$ mouse of LPS in $1 \mathrm{ml}$ of $0.5 \%$ carboxymethylcellulose (CMC) was injected into the pouch. Controls received the vehicle alone. Lovastatin or pravastatin, at $10 \mathrm{mg} / \mathrm{kg}$, was orally administered to mice 20 hours, 12 hours, and 15 minutes before LPS injection. Four hours after LPS, animals were anesthetized, blood was collected from the retroorbital plexus, mice were killed by cervical dislocation, and livers were collected. The pouches were washed with $1 \mathrm{ml}$ of saline, the lavage fluids cooled on ice, and volumes recorded; $50 \mu \mathrm{l}$ were used for cell counting after staining with erythrosin B. Exudates were centrifuged, and supernatants were collected and stored at $-20^{\circ} \mathrm{C}$ until use.

\section{Chemokines}

MCP-1 levels in cellular supernatants were measured by a specific ELISA, as described (Sironi et al, 1997). MCP-1 levels in pouch exudate were evaluated using a specific sandwich ELISA (Benfer-Scheller, Milan, Italy) with a sensitivity limit of $40 \mathrm{pg} / \mathrm{ml}$.

\section{Cholesterol and HMG-CoA Reductase Activity}

Serum total cholesterol was assayed using a standard enzymatic method (Sigma). Protein concentration in liver and EC samples was determined using a Bio-Rad Protein assay (Bio-Rad Laboratories, Munich, Germany). The activity of HMG-CoA reductase was determined as described by Kita et al (1980). Briefly, liver or cellular homogenates, resuspended in a $20 \mathrm{~mm}$ imidazole solution, $\mathrm{pH} 7.4$, containing $5 \mathrm{~mm}$ dithiotreitol and $5 \mathrm{U}$ alkaline phosphatase, were incubated for 30 minutes at $37^{\circ} \mathrm{C}$. Then $87 \mu \mathrm{M}$ of $\left[{ }^{14} \mathrm{C}\right] \mathrm{HMG}-\mathrm{CoA}$ in a $40 \mathrm{~mm}$ D-glucose-6-phosphate solution containing 12 mм dithiothreitol, $4 \mathrm{~mm}$ NADPH, and $10 \mathrm{~mm}$ EGTA were added, and samples were incubated for 60 minutes at $37^{\circ} \mathrm{C}$. The reaction was stopped with $18.5 \% \mathrm{HCl}$, and after the addition of $29 \mu \mathrm{M}\left[{ }^{3} \mathrm{H}\right] \mathrm{meva}-$ lonolactone as internal standard, samples were incubated overnight at $4^{\circ} \mathrm{C}$. After centrifugation at 3000 rpm for 20 minutes, $\left[{ }^{3} \mathrm{H}\right]$ mevalonolactone and $\left[{ }^{14} \mathrm{C}\right]$ mevalonolactone were co-purified from each sample by elution on a $20 \times 20 \mathrm{~mm}$ Kiesegel plate (Merck), using acetone:toluene $(1: 1, v / v)$ as mobile phase, and identified using Rhodamine $G$. The $R f$ value of the band was assessed by a parallel run of an unlabeled standard mevalonolactone. The $\left[{ }^{3} \mathrm{H}\right] \mathrm{meval}-$ onolactone and $\left[{ }^{14} \mathrm{C}\right]$ mevalonolactone radioactivity was counted using a $\beta$-counter scintillator, and the activity of HMG-CoA reductase was calculated and expressed as pmol[ $\left[{ }^{14} \mathrm{C}\right] \mathrm{mevalonolactone}$ formed/minutes/mg protein.

\section{Statistical Analysis}

Statistical significance was determined by Dunnett's test.

\section{Acknowledgements}

This work was supported by EC contracts No. BMH4CT98-2343 and BMH4-CT98-3277. This work has been carried out, in part, under a research contract with Consorzio Autoimmunità Tardiva C.A.U.T., Pomezia, Italy, within the "Programma Nazionale Farmaci-terza fase" of the Ministero dell'Università e della Ricerca Scientifica e Tecnologica. The contribution of "Centro per lo Studio dello Scompenso Cardiaco," University of Brescia, Italy, is acknowledged.

\section{References}

Anonymous (1994). Randomized trial of cholesterol lowering in 4444 patients with coronary heart disease: The Scandinavian Simvastatin Survival Study (4S) [see comments]. Lancet 344:1383-1389.

Anonymous (1998). Influence of pravastatin and plasma lipids on clinical events in the West of Scotland Coronary Prevention Study (WOSCOPS). Circulation 97:1440-1445.

Bhatnagar D (1998). Lipid-lowering drugs in the management of hyperlipidaemia. Pharmacol Ther 79:205-230.

Boring L, Gosling J, Cleary M, and Charo IF (1998). Decreased lesion formation in CCR2 -/- mice reveals a role for chemokines in the initiation of atherosclerosis. Nature 394: 894-897.

Corsini A, Maggi FM, and Catapano AL (1995a) Pharmacology of competitive inhibitors of HMG-CoA reductase. Pharmacol Res 31:9-27.

Corsini A, Raiteri M, Soma MR, Bernini F, Fumagalli R, and Paoletti R. (1995b) Pathogenesis of atherosclerosis and the role of 3-hydroxy-3-methylglutaryl coenzyme A reductase inhibitors. Am J Cardiol 76:21A-28A.

Corsini A, Pazzucconi F, Arnaboldi L, Pfister P, Fumagalli R, Paoletti R, and Sirtori CR (1998). Direct effects of statins on the vascular wall. J Cardiovasc Pharmacol 31:773-778.

Downs JR, Clarfield M, Weis S, Whitney E, Shapiro DR, Beere PA, Langerdorfer A, Stein EA, Kruyer W, and Gotto AM (1998). Primary prevention of acute coronary events with lovastatin in men and women with average cholesterol levels. JAMA 279:1615-1622. 
Goldstein JL and Brown MS (1990). Regulation of the mevalonate pathway. Nature 343:425-430.

Gu L, Okada Y, Clinton SK, Gerard C, Sukhova GK, Libby P, and Rollins BJ (1998). Absence of monocyte chemoattractant protein-1 reduces atherosclerosis in low density lipoprotein receptor-deficient mice. Mol Cell 2:275-281.

Guijarro C, Blanco-Colio LM, Ortego M, Alonso C, Ortiz A, Plaza JJ, Diaz C, Hernandez G, and Egido J (1998). 3-Hydroxy-3-methylglutaryl Coenzyme A reductase and isoprenylation inhibitors induce apoptosis of vascular smooth muscle cells in culture. Circ Res 83:490-500.

Ikeda $U$ and Shimada K (1999). Statins and monocytes. Lancet 353:2070.

Kim S-Y, Guijarro C, O’Donnel MP, Kasiske BL, Kim Y, and Keane WF (1995). Human mesangial cell production of monocyte chemoattractant protein-1: Modulation by lovastatin. Kidney Int 48:363-371.

Kita T, Browns MS, and Goldstein JL (1980). Feedback regulation of 3-hydroxy-3-methylglutaryl coenzyme A reductase in livers of mice treated with mevilonin, a competitive inhibitor of the reductase. J Clin Invest 66:1094-1100.

Kluft C, de Maat MP, Gevers Leuven JA, Potter van Loon BJ, and Mohrschladt MF (1999). Statins and C-reactive protein. Lancet 353:1274.

Kurakata S, Kada M, Shimada Y, Komai T, and Nomoto K (1996). Effects of different inhibitors of 3-hydroxy-3methylglutaryl coenzyme A (HMG-CoA) reductase, pravastatin sodium and simvastatin, on sterol synthesis and immunological functions in human lymphocytes in vitro. Immunopharmacology 34:51-61.

MacMahon S, Sharpe N, Gamble G, Hart H, Simes J, and White $H$ (1998). Effects of lowering average of below-average cholesterol levels on the progression of carotid atherosclerosis: Results of the LIPID Atherosclerosis Substudy. LIPID Trial Research Group. Circulation 97:17841790.

Mantovani A, Bussolino F, and Introna M (1997). Cytokine regulation of endothelial cell function: From molecular level to the bed side. Immunol Today 18:231-239.

Ness GC, Eales S, Lopez D, and Zhao Z (1994). Regulation of 3-Hydroxy-3-methylglutaryl coenzyme A reductase gene expression by sterols and nonsterols in rat liver. Arch Biochem Biophys 308:420-425.

O'Donnell MP, Kasiske BL, Kim Y, Atluru D, and Keane WF (1993). Lovastatin inhibits proliferation of rat mesangial cells. J Clin Invest 91:83-87.

Ortego M, Bustos C, Hernandez-Presa MA, Tunon J, Diaz C, Hernandez G, and Egido J (1999). Atorvastatin reduces NF-kB activation and chemokine expression in vascular smooth muscle cells and mononuclear cells. Atherosclerosis 147:253-261.

Pan HY, DeVault AR, Wang-Iverson D, Ivashkiv E, Swanson NB, and Sugerman AA (1990). Comparative pharmacokinetics and pharmacodynamics of pravastatin and lovastatin. J Clin Pharmacol 30:1128-1135.
Park YS, Guijarro C, Kim Y, Massy ZA, Keane WF, and O'Donnell MP (1998). Lovastatin reduces glomerular macrophage influx and expression of monocyte chemoattractant protein-1 mRNA in nephrotic rats. Am J Kidney Dis 31:190194.

Reape TJ and Groot PHE (1999). Chemokines and atherosclerosis. Atherosclerosis 147:213-225.

Ridker PM, Rifai N, Pfeffer MA, Sacks FM, Moye LA, Goldman S, Flaker GC, and Braunwald E (1998). Inflammation, pravastatin, and the risk of coronary events after myocardial infarction in patients with average cholesterol levels. Circulation 98:839-844.

Rollins BJ (1997). Chemokines. Blood 90:909-928.

Romano M, Sironi M, Toniatti C, Polentarutti N, Fruscella P, Ghezzi P, Faggioni R, Luini W, vanHinsbergh V, Sozzani S, Bussolino F, Poli V, Ciliberto G, and Mantovani A (1997). Role of IL-6 and its soluble receptor in induction of chemokines and leukocyte recruitment. Immunity 6:315-325.

Rosenson RS, Tangney CC, and Casey LC (1999). Inhibition of proinflammatory cytokine production by pravastatin [letter]. Lancet 353:983-984.

Ross R (1993). The pathogenesis of atherosclerosis: A perspective for the 1990s. Nature 362:801-809.

Sironi M, Pozzi P, Polentarutti N, Benigni F, Coletta I, Guglielmotti A, Milanese C, Ghezzi P, Vecchi A, Pinza M, and Mantovani A (1996). Inhibition of inflammatory cytokine production and protection against endotoxin toxicity by benzydamine. Cytokine 8:710-716.

Sironi M, Milanese C, Vecchi A, Polenzani L, Guglielmotti A, Coletta I, Landolfi C, Soldo L, Mantovani A, Pinza M (1997). Benzydamine inhibits the release of tumor necrosis factor-a and monocyte chemotactic protein-1 by Candida albicansstimulated human peripheral blood cells. Int J Clin Lab Res 27:118-122.

Sozzani S, Locati M, Allavena P, Van Damme J, and Mantovani A (1996). Chemokines: A superfamily of chemotactic cytokines. Int J Clin Lab Res 26:69-82.

Takeya M, Yoshimura T, Leonard EJ, and Takahashi K (1993). Detection of monocyte chemoattractant protein-1 in human atherosclerotic lesions by an anti-monocyte chemoattractant protein-1 monoclonal antibody. Hum Pathol 24:534-539.

Terkeltaub R, Solan J, Barry M, Santoro D, and Bokoch GM (1994). Role of the mevalonate pathway of isoprenoid synthesis in IL-8 generation by activated monocytic cells. J Leukoc Biol 55:749-755.

van Vliet AK, Negre-Aminou P, van Thiel GC., Bolhuis PA, and Cohen LH (1996). Action of lovastatin, simvastatin, and pravastatin on sterol synthesis and their antiproliferative effect in cultured myoblasts from human striated muscle. Biochem Pharmacol 52:1387-1392.

Vaughan C, Murphy MB, and Buckley BM (1996). Statins do more than just lower cholesterol. Lancet 348:1079-1082. 